\title{
Destroying Krishna Imagery. \\ What are the Limits of Academic and Artistic Freedom?
}

Maruška Svašek

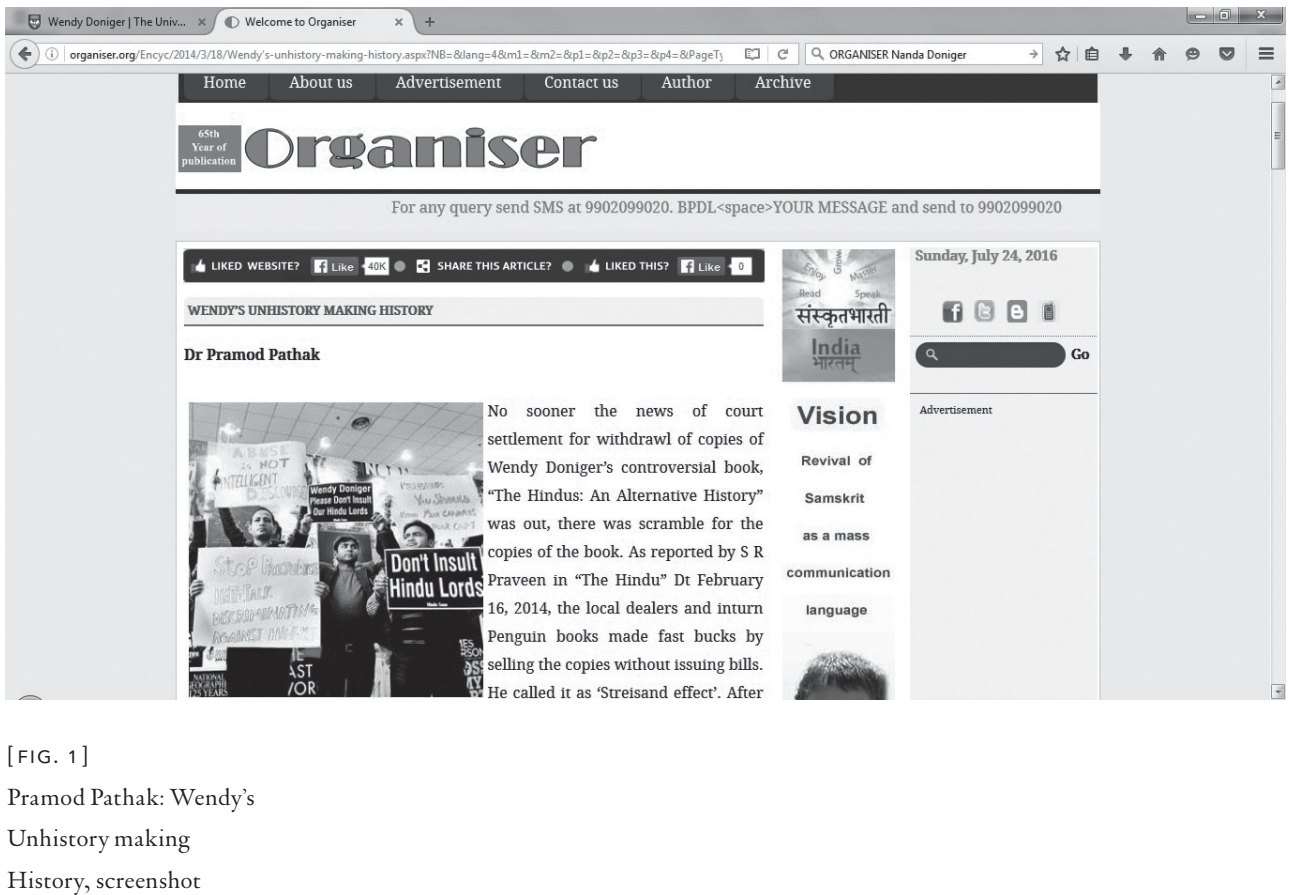

A photograph published in 2014 by Organiser, a weekly magazine based in New Delhi, shows a group of Indian demonstrators holding up various placards. »Don't insult Hindu Lords « is printed on one of them; »Stop Prejudice Hate Talk Discriminating against Hindus« and »Abuse is not intelligent discourse are written on others. Another placard addresses the target of the demonstration: »Wendy Doniger Please don't insult our Hindu Lords.«(Fig. I).

An Internet search for »Wendy Doniger« leads to the other side of the globe, to the prestigious University of Chicago Divinity School. The University website states that Professor Doniger specializes in Hinduism and 


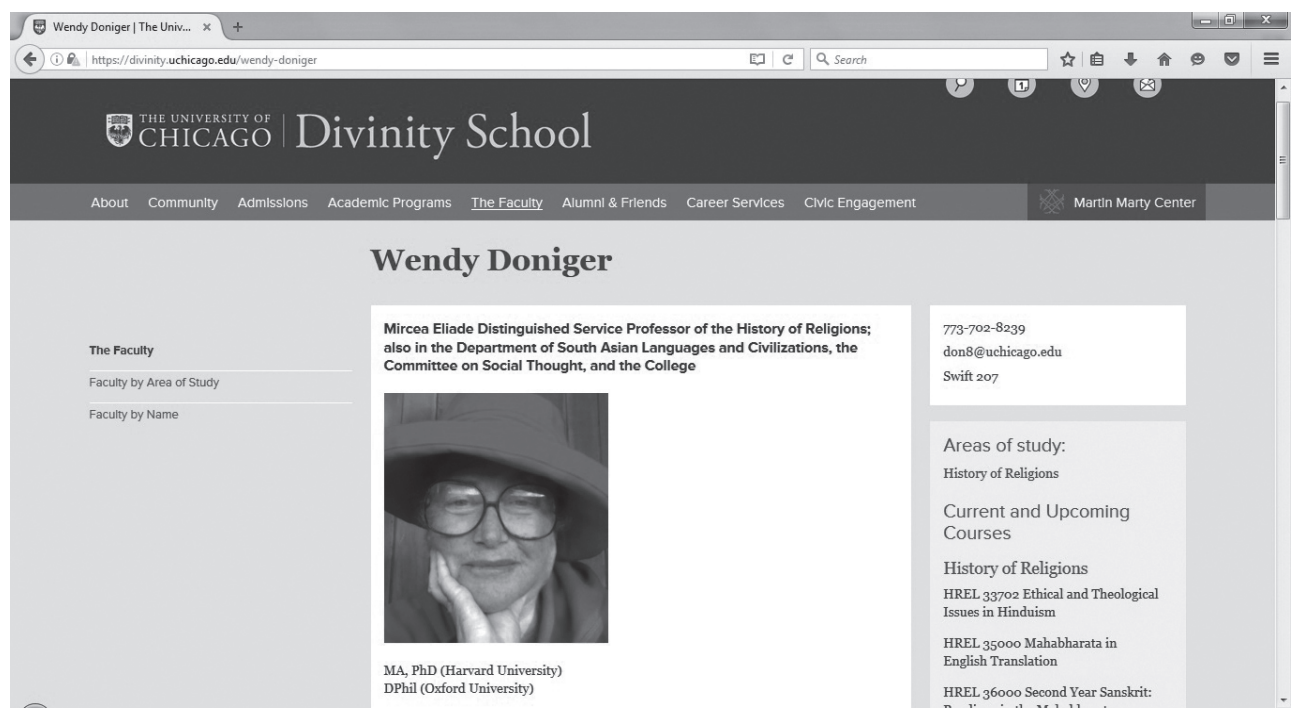

[FIG. 2]

Wendy Doniger's home page on the University of Chicago's website, screenshot

mythology, has published over forty books on related topics in these fields, and received her postgraduate degrees from Harvard University and the University of Oxford. In Chicago, Doniger holds the position of Mircea Eliade Distinguished Service Professor of the History of Religions and is associated with the Department of South Asian Languages and Civilizations and to the Committee on Social Thought (Fig. 2). Clearly, she is a highly successful, internationally renowned scholar who is considered an expert in her field. So why the accusations of blasphemy and prejudice? What compelled a group of Hindus to gather and protest against her? 
In Organiser, this photograph was used to illustrate an article by Pramod Pathak, a Vedic scholar based in Goa, entitled »Wendy's unhistory making history.« The piece was highly critical of Doniger's latest book, The Hindus. An Alternative History, and accused her of misinterpretation and cultural bias. ${ }^{\mathrm{I}}$ Pathak makes his own sympathy with the protesters amply clear:

In this book Wendy has lost her bearing. She appears to have done away with the precision in her scholarship she had shown in her earlier works. It is a pity that the western scholars have not yet come out of their colonial mindset and the Indian secularists have not come out of the slavish mentality. They write false histories of Asia and the Indian subcontinent. ${ }^{2}$

This chapter explores the furore around Doniger's publication, analyzing the uproar in the context of many other controversies around Hindu textual and visual imagery. To understand the dynamics of such image wars, ${ }^{3}$ the analysis takes a multidimensional approach, exploring geographic, social, material, discursive, and affective dimensions of cultural production and destruction. It also takes into consideration the wider issues of Hindu identity politics in colonial and postcolonial India and discusses the campaign against Doniger in light of the current political climate in which supporters of Hindutva ideology have frequently mustered other protest campaigns, not only against certain books but also against other artifiacts deemed »unacceptable, « such as contemporary art works, photographs, popular consumer goods, and works of architecture. The chapter will also address global aspects of image circulation in a world where some Hindus in India and diasporic settings have used the Internet to demand the 
withdrawal and destruction of particular academic and artistic works, while others have employed the same digital media to argue their support for such works.

\section{Whose history? Which truth?}

Accusing Doniger of writing "unhistory, " Pathak argued that Doniger and her supporters were stuck in the colonial past, a time when Western scholars had ridiculed and exoticized Hinduism and when Indian secularists had turned their backs on local traditions, copying the lifestyles of their oppressors. The result, Pathak claimed, was a distorted picture of Indian history and culture: an »unhistory« that needed to be erased. It was not only necessary to do this in order to assure the production of good scholarship; it was also a moral obligation, as non-Hindu scholars needed to be taught respect for sacred Hindu values.

Before taking a closer look at colonial perceptions of Hindu cultural forms, Doniger's own intentions need to be scrutinized. Why did she choose to shed light on alternative historical discourses of Hinduism? How did she react to her critics? As the book title suggests, Doniger aimed to present a different historical perspective on Hinduism. This, however, was not meant to be an ethnocentric, patronizing colonial perspective, as her critics suggested. Instead, she sought to reveal compassionate and tolerant dimensions in the history of Hinduism that, she claimed, were absent in the very dominant accounts provided by male, high-caste Brahmins. In an interview on May 17, 2013 with $\mathrm{PhD}$ student Sonam Kachru that was freely available on her university 
website ${ }^{4}$ she explained that when she had studied Sanskrit many years earlier, she had been not so interested in »respectable things « such as the Dharmashastras and the Laws of Manu, widely regarded as key texts by Sanskrit scholars, but had been attracted rather by mythological narratives (»I love stories«) that reflected the under-represented voices of women, animals, and the suppressed castes. Doniger explained that her fascination with the oppressed stemmed from her own family background and the historical period that had shaped political debate during her early adulthood. »The world in which I grew up sensitized me, «she said. Born in the Us at the end of World War II to a left-leaning, Jewish family and influenced by the civil rights movement, she had been struck by colorful Hindu texts such as the Kamasutra and the Mababarata. The »alternative « voices of the oppressed, she said, »sang out at $[$ her $]$. She was also attracted to Hindu philosophy and art and, though not a practicing Hindu, the Hindu paradigm made sense to her as she tried to deal with the difficulties of life. In addition, her own ideas »resonate[d] with [the more colorful and abundant] Hindu aesthetics.«

In her controversial book, the alternative history was partly presented through references to texts from the Vedas, ritual artifacts, and temple sculptures that had erotic themes. In her interview with Kachru, however, Doniger disagreed that she had written an overly sexualized account: »There is hardly sex in it anywhere, it is madness! « Her opponents accused her of misinterpreting and ridiculing Hindu symbolism, for example by describing the Shiva linga as Shiva's phallus and by choosing a picture depicting Krishna mounted on a horse composed from the shapes of naked women. This image was in fact displayed on the book's cover (Fig. 3). 


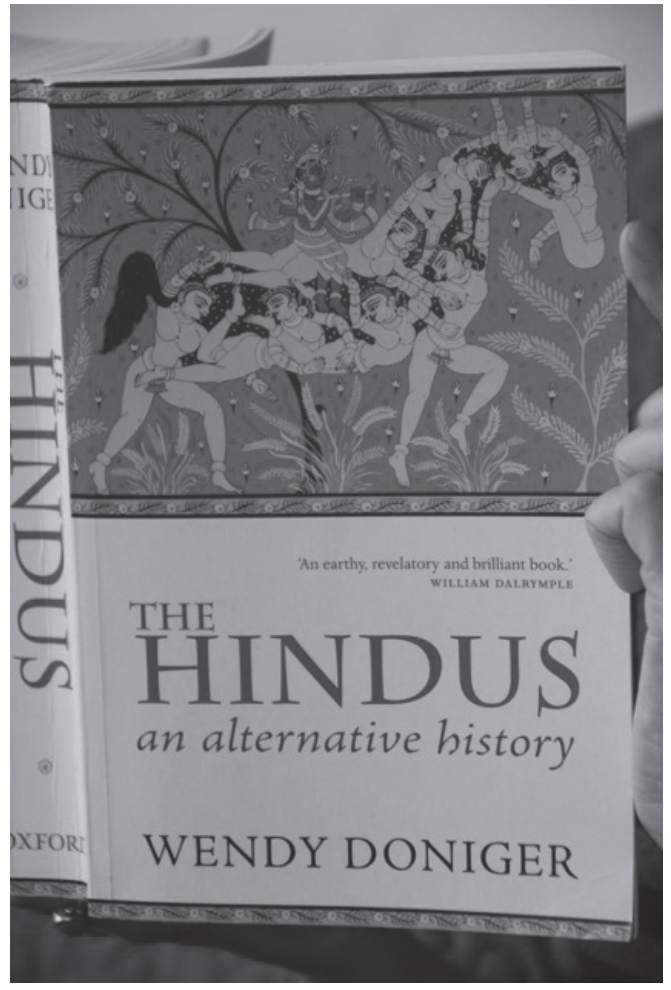

One of her Mumbai-based critics was Devdutt Pattanaik, who describes himself on his website as »a renowned author, mythologist, and leadership consultant, whose work focuses on deriving management insights from mythology to provide a very Indian approach to modern business. «5 Having written over thirty popular books about Hinduism for a wide, mostly non-academic readership, he emailed the American scholar to ask her some questions about her new book. ${ }^{6}$ He explained that some of his relatives, in particular his mother 
and his aunts, disagreed with her stance on the Shiva linga, and so he wanted to know, "Whose truth is the truth - that of the believers or that of the research scholar? «Doniger responded as follows:

There is no one correct truth here. Historically, the Shiva-linga was indeed understood as a representation of the phallus of Shiva; you can see this from visual representations like the Gudimallam linga and from stories in the Puranas about the origin of the linga from the body of Shiva. But since the $19^{\text {th }}$ century reforms of Hinduism, many Hindus have entirely lost these historical associations and see the Shiva-linga as a purely abstract symbol. So your mother and aunts are right, but the scholars of the history of Hinduism are also right. ${ }^{7}$

Her reply was clearly intended to demonstrate that no singular interpretation could hold a monopoly on truth.

\section{Aestheticizing the »erotic «}

For many of Doniger's detractors, the book's cover was itself highly inflammatory. In their eyes, it depicted »Lord Krishna [...] sitting on buttocks of a naked woman surrounded by other naked women, « and the use of this image was »tantamount to invading the sacredness attached to Sri Krishna. $\ll^{8}$ Pattanaik made the following comment about the contentious image. 
This is a popular theme in Patta Paintings of Orissa; more often, the women collectively give shape to an elephant or a temple-shaped Kandarpa Ratha, chariot of the love-god. Such images have been around for a long time. The erotic content is often overlooked, or may occasionally evoke mild amusement. As the book discusses women and horses and patriarchy in the Hindu context, the image even seems appropriate. But when a Jewish American scholar puts it on her book about the Hindus, it can - in a time of political opportunism, religious intolerance, and scholastic puritanism be construed as provocative and insensitive. ${ }^{9}$

He alluded to the changing and conflicting symbolism and emotional impact of religious images that reflect struggles for cultural ownership and authority in the often connected fields of religion, politics, and academia. Across the globe, disputes over the right to reproduce or ban imagery are instrumental in struggles for influence. ${ }^{10}$ Representations referring to fertility, sexuality, and reproduction are frequently regulated by both unspoken taboos and strict, explicit regulations. In the case of Hinduism, erotic imagery has evoked different emotional reactions throughout history, as is also outlined by Monica Juneja in her contribution to this volume. Different producers, users, and commentators have interpreted, experienced, and judged sexually explicit depictions of gods in distinct ways. ${ }^{\text {II }}$ In some contexts, such images have been perceived and discursively constructed as manifestations of the sacred. In others, they have been experienced as visually appealing objects of transcendental beauty or, in sharp contrast, as shocking, shameful representations, deplorable on moral grounds. This transitional 
process is tied up with the ability of material objects to evoke a wide variety of feelings, from awe and devotion to anger and outrage. ${ }^{\text {I2 }}$

As Richard Davis pointed out in an exploration of the social lives of Indian artifacts, object-oriented affective causalities and interactions are influenced by the ways people engage sensorially with images: »different ways of seeing animate the object seen in new ways. $\ll^{13}$ This implies that when the same or similar artifacts speak differently to the senses, they are instrumental in the production of different subjectivities. A statue depicting Shiva, for example, will encourage a practicing Hindu to experience a proximity to the divine when interacting with it, not only through vision, but also in ritual practice that includes touch, smell, and sound. By contrast, when framed as »art« or »culture« in a museum or gallery, the same statue will appeal most of all to the eye, whereby the »museum effect ${ }^{14}$ produces a specific kind of experience, encouraging visitors to animate the object on display »through visual and interpretative attentiveness. $\ll^{15}$ Distinct modes of engagement can also spill over into other contexts, transgressing boundaries between different socio-spatial settings. During research in Tamil Nadu in 2010 and 20II, I saw museum visitors putting their hands together in a ritual sign of respect for statues displayed in the art historical section of the Government Museum in Chennai, thus redefining the objects of heritage as active religious agents. By contrast, in the ancient Hindu temples in Kumbakonam, fine art students made pencil sketches of Hindu reliefs that embellished the temple walls. ${ }^{16}$ This act of artistic appropriation was, however, limited to the outer temple space, and could not take place in the inner, most sacred sanctum sanctorum. ${ }^{17}$

Highly significant for the focus of this chapter are those occasions when religious practitioners object to these types of boundary fluidity, particularly 
when they deem specific appropriations of religious imagery in non-religious fields to be contextually apocryphal or blasphemous and may therefore demand the destruction of the object in question. ${ }^{18}$ As we shall see, this is exactly what happened in the case of Doniger's publication, where both the artistic rendering of Krishna on the book's cover and the academic text became targets of an iconoclastic campaign.

\section{Censorship, destruction, and calls for freedom}

The Hindu Group Shiksha Bachao Andolan Samiti, an education reform movement headed by Dina Nath Batra, led many of the protests against the book and filed the charges against Penguin, its publisher. The group claimed that Doniger's take on Hinduism had hurt »the religious feelings of millions of Hindus « and accused her of violating sections of the Indian Penal Code that criminalize causing enmity between religious communities and that restrict free speech in cases where it might cause unacceptable offense. Central to the lawsuit were the violations of section 295A, which stipulates:

Whoever, with deliberate and malicious intention of outraging the religious feelings of any class of citizens of India, by words, either spoken or written, or by signs or by visible representations or otherwise, insults or attempts to insult the religion or the religious beliefs of that class, shall be punished with imprisonment of either description for a term which may extend to three years, or with fine, or with both. ${ }^{19}$ 
Batra's group accused Doniger, for example, of "pure and total blasphemy," arguing that her book insinuated that in the Rāmāyaṇa, a Sanskrit epic poem that depicts the duties of relationships, Sita had sexual intercourse with her husband Rama's brother. ${ }^{20}$ To them, this was a highly insulting claim that had to be properly dealt with by the law. The existence of section 295A gave them that opportunity.

Their call for the destruction of Doniger's publication highlighted the fact that protesters not only decried the arguments presented in the work, but also the book itself. In other words, the material existence of both the book and the visual reproduction on its cover were as much a part of the problem as the abstract theories they articulated. As an artifact, the book could be interpreted in many ways, but undeniably the texts and reproductions involved some sexual themes, which allowed the detractors to denounce the »lewdness« of the work and argue that any religious symbolism involved in the reproductions was of secondary importance to the author and publishers. Underlying their anger were specific ideas about Hindu identity and morality, central to the ideology of »Hindutva«, a concept formulated in 1923 by Vinayak Damodar Savarkar in the pamphlet Hindutva: Who is a Hindu? It was published at a time when nationalists who resisted British colonial rule had »little agreement on which mix of industrialization, westernization, straditionalism, e egalitarianism and individualism was most desirable « in a future independent Indian state. ${ }^{21}$ Different schools of thought were developed, »from a fascist-style Hindu Right, to a communist-inspired Left. $\aleph^{22}$ Savarkar claimed that the whole »Hindurace« shared one specific history and identity that could be conceptualized as Hindutva (Hindu-ness). The discourse on Hindu cultural unity was further 
propagated by the Rashtriya Swayamsevak Sangh (the national volunteer corps or RSS), an organization established in 1925. In the 1930s, one of its leaders, Golwalkar, even referred to Nazi Germany as a potential political model for the future Indian state. While accusing Islam and Christianity of being religions alien to authentic India, Savarkar admired their »fierce unity of faith, social cohesion and valorous fervour « and called for »theocratic patriotism « and »a state powerful enough to weld [Hindus] into an organic whole. $\ll^{23}$ Shiksha Bachao Andolan Samiti argued that Doniger's account of Hinduism disagreed with the true understanding of Hinduism as promoted by Hindutva.

As the protests against the book continued for a number of years, Penguin, by now merged with another publisher and named Penguin Random House, eventually decided on an out-of-court settlement that stipulated withdrawing the book from circulation in India and announcing the destruction of the remaining copies in February 2014. ${ }^{24}$ This decision provoked a counter-wave of protests by Indian writers, filmmakers, artists, and intellectuals based in India and abroad. ${ }^{25}$ The issue was widely discussed in the Indian media, on social media platforms, and at several universities. Some of the recorded debates were uploaded to YouTube. One of these broadcasts was the 20-minute feature Why no Wendy Doniger over chai?, produced by the India-based NDTV program The Social Network in February 2014 (Fig. 4). In an act of defiance, the program invited a number of Indian critics to express their opinion about the withdrawal of the book. ${ }^{26}$ At the start, several public figures read out excerpts of various forbidden or contentious texts, and this was followed by a panel discussion. The panel included Akila Ramalingam, a Delhi-based lawyer who argued that it 


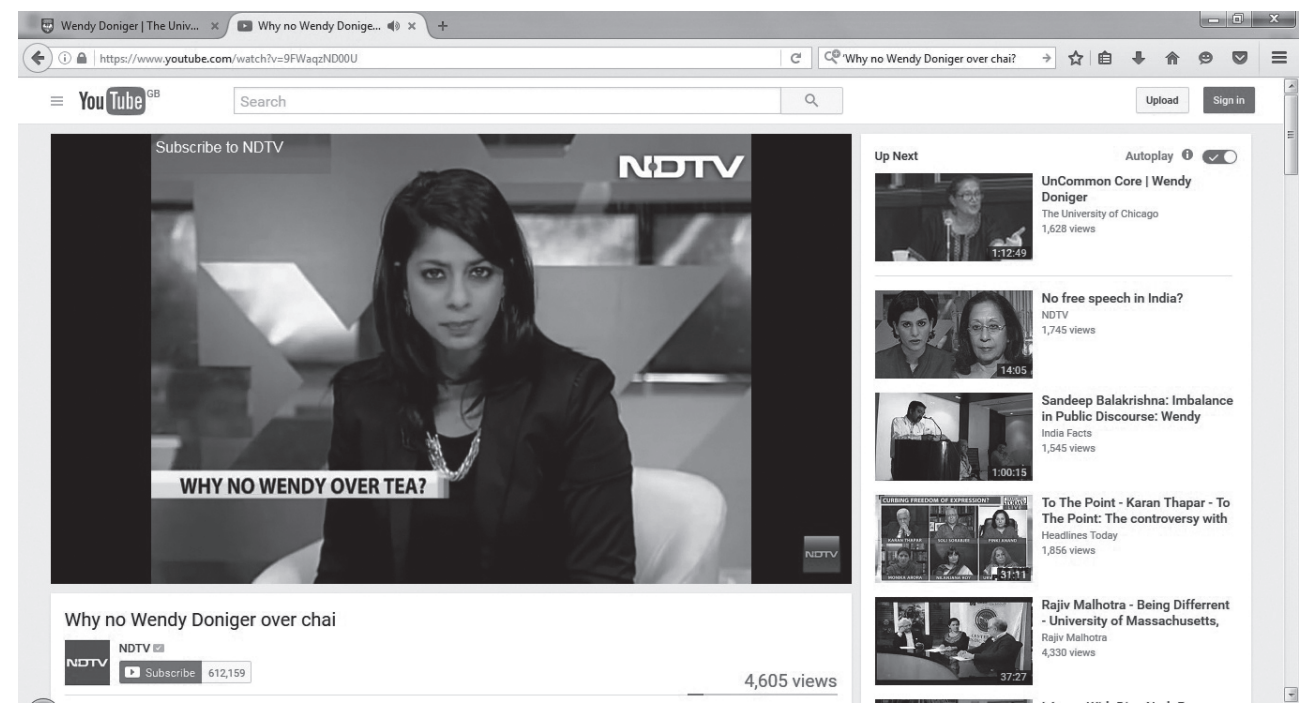

[FIG. 4]

NDTV program's website

showing The Social Network

in February 2014, screenshot

was of crucial importance to fight not only for free speech, but also for the rights of readers. She argued that the publisher's decision was »not conducive to democracy, « as it set a dangerous precedent, opening »the floodgates to censorship. Certain »professional offense takers, « she warned, would initiate litigation after litigation and, if successful, would stifle opposition.

In an open letter to the Times of India, the writer and Man Booker Prize winner Arundhati Roy indicated that she was shocked most of all by the publisher's decision to pulp remaining copies of the book. Speaking to BBC Radio 
on February I4, 20I4, she explained that during her own book launches, it was not unusual for protesters to come in to »smash things. ${ }^{27}$ This made the support of one's publisher all the more important. She considered surrendering to »fanatics who are connected to a very big network of righteous fundamentalists" as »a shift in submitting to a growing atmosphere of intolerance« and claimed that even BJP leader Narendra Modi ${ }^{28}$ would find protesters' interpretations of Doniger's book »insane.« Addressing Penguin, she appealed to the moral responsibility of the publisher:

You have published some of the greatest writers in history [...]. You have stood by them as publishers should, you have fought for free speech against the most violent and terrifying odds. And now, even though there was no fatwa, no ban, not even a court order, you have not only caved in, you have humiliated yourself abjectly before a fly-by-night outfit by signing settlement. Why? You have all the resources anybody could possibly need to fight a legal battle. Had you stood your ground, you would have had the weight of enlightened public opinion behind you, and the support of most - if not all - of your writers. ${ }^{29}$

Her reference to »fatwas, « rulings issued by Muslim religious leaders, which are sometimes death sentences against proclaimed blasphemers, has not infrequently been used against others, most infamously Salman Rushdie after the publication of his book, The Satanic Verses..$^{3 \circ}$ By contrast with these more violent cases, the demand for the destruction of Doniger's book appeared relatively moderate in the wider context of religious fundamentalism that threatened 
freedom of speech in the region. ${ }^{3}$ Most Indian politicians refrained from public comment. Government minister Jairam Ramesh, a member of the Congress Party and a self-proclaimed Hind-Budh, ${ }^{32}$ was one of the exceptions, and he also compared the case to non-Hindu acts of religious extremism. He contended, »The book is not blasphemous. [Doniger] is a scholar without any political agenda. The organisation that demanded Penguin take such action is clearly »some Taliban-type outfit." It is distorting and destroying our liberal traditions « ${ }^{33}$ (emphasis M.S.). Some organizations outside India also joined the discussion. In the Us, the National Book Critics Circle ${ }^{34}$ urged Penguin to reverse its »deplorable decision to remove The Hindus from circulation in the country, a de facto act of self-censorship that will only contribute to a further rolling back of free speech in India. «35

Ironically, the planned destruction led to a great increase in sales, and by the time Penguin Random House had organized the logistics to carry out the destruction of the offending text, all copies were sold out. As Doniger commented in 2016 ,

Penguin Random House did agree to pulp all remaining copies, but as it turned out - not a single book was destroyed; all extant copies were quickly bought up from the bookstores. The words »banned « and "pulped, " however, continued to be used to fan the flames of media indignation. ${ }^{36}$ 


\section{Section 295A: Legal mechanisms and the politics of religious sentiments}

The case, however, put a spotlight on the ways the Indian Penal Code had been used to limit freedom of speech. In its defense of the out-of-court settlement, Penguin Random House argued that, while international editions of the book would still be available, »the Indian Penal Code, and in particular section 295A of that code, will make it increasingly difficult for any Indian publisher to uphold international standards of free expression, « as publishers had »a moral responsibility to protect [their] employees against threats and harassment. « ${ }^{37}$ In comments published in numerous papers around the world, including Britain's The Guardian, Doniger herself also criticized section 295A, stating that she was »deeply troubled by what [the out-of-court settlement] foretells for free speech in India in the present, and steadily worsening, political climate. $\ll^{38}$ In her view, the »true villain [was] the Indian law that makes it a criminal rather than civil offense to publish a book that offends any Hindu, a law that jeopardizes the physical safety of any publisher, no matter how ludicrous the accusation brought against a book.«39

In 2016, the Journal of the American Academy of Religion published the outcomes of a 2014 discussion forum that critically investigated the implications of section 295A for academics and other cultural producers in India, entitled »Roundtable on Outrage, Scholarship, and the Law in India.« Four scholars contributed, including C.S. Adcock (Department of History, Washington University, St. Louis), Brian Pennington (Center for the Study of Religion, Culture, \& Society, Elon University), Anantanand Rambachan (Department of Religion, St. Olaf College, Northfield), Rupa Viswanath (Centre for Modern Indian 
Studies, University of Göttingen), and Doniger herself. The articles examined the historical reasons leading to the introdution of Section 295A in 1927 and explored its workings in colonial and postcolonial India. The legislation had been conceived by the British in a reaction to religious unrest caused by the Arya Samaj, a reformist Hindu organization established by Swami Dayananda Saraswati in 1875 . The organization employed a »mocking, derisive tone of religious polemics « in its conversion campaign and ridiculed people of other religious persuasions, especially Muslims. ${ }^{\circ}{ }^{\circ}$ While the new legislation was thus »enacted as a legal tool to restrain the religious criticism associated with proselytizing, « it seemed to be highly ineffective. During the I930s, »the tone of polemics was arguably worse. $\aleph^{41}$ In Adcock’s words,

The purpose was to curb religious violence by curbing provocative speech. But the strategic field the law put into place worked differently: it extend ed the strategic value of demonstrating that passions had been aroused that threatened the public peace, in order to induce the government to take legal action against one's opponents. Section 295A thus gave a fillip to the politics of religious sentiment. ${ }^{42}$

Viswanath added that the legislation tended to serve the interests of powerful elites who strategically used the language of »hurt sentiments« to increase their influence. »The Doniger affair, «she argued, demonstrated »how those sentiments are deployed to preserve high-caste, Hindu majoritarian prerogatives by means of the implicit threat of violence. She emphasized, however, that rallies for »free speech « also often concealed differences in power, as those in more 
powerful positions were better connected to successfully defend their opinions. ${ }^{43}$ Nevertheless, it seems clear that section 295A did not restrain, but rather fired up religious and political tensions. Pennington concluded,

The resulting politics of religious sentiment has resulted in repeated attacks on the scholarly study of religion in India and the Indian diaspora. The legal and religious culture that produces such a problematic politics of religious sentiment poses an ongoing and serious threat to the shared foundational values of the international academy. ${ }^{44}$

\section{Representing a colonial mindset?}

To return to the protest against Doniger's book, her opponents not only filed charges, but also produced visual images to express their contempt and challenge the American scholar. Some anti-Doniger posters were reproduced on the website of Hindu Existence, a digital forum that asks »Hindus from everywhere« to »please send reports and pictures about our status, " with the aim to »create a solidarity in Global Hindus. «45 One of the posters showed a photograph of the author's head, with the addition of a crown of thorns, a cross, the Star of David, an exaggerated nose, and the words »STOP NUISANCE You Missionary!!!« printed over her mouth. On the right, it said »Right to Express? Right to Research?? Right to Attack Hindu Dharma??? HOW FEELING????? A text at the bottom proclaimed: »Wendy Doniger, the writer of THE HINDU is a definite Christian Agent.« 
The poster accused Doniger of an ethnocentric colonialist Christian missionary mindset and a Jewish-Marxist bias.

There is no denying that, particularly during the colonial period, many Christian Europeans derided Hindu sacred depictions. Art historian Partha Mitter explored such reactions from European travellers and Victorian scholars between the $16^{\text {th }}$ and $19^{\text {th }}$ centuries, providing many examples of highly negative responses to ancient Indian temple art, artifacts, murals, and pictures. ${ }^{46}$ J.H. van Lindschoten, who spent some years in India in the $1580 \mathrm{~s}$, spoke for example of »fearefull, horrible and devilish forms, " and temples »with so evill favored and uglie shapes, that to enter there in it would make a mans hayre stand upright. ${ }^{47}$ In the Victorian period, Indian depictions of nudity and erotic scenes were either regarded as proof of the primitive sexual drives of an uncivilized race or alternatively were exoticized as a characteristic of a free and unrestrained people, unspoiled by the constraints of Western modernity. As Doniger herself noted, »the puritanical Protestant ministers who evangelized India after I8 33 loathed the eroticism of the temples, the temple dancers, and the amatory excesses of the god Krishna. $\ll^{48}$ By contrast, the »fraction of Hinduism that appealed to Protestant, evangelical tastes was firmly grounded in the other path of Hinduism, the philosophical, renunciant path. ${ }^{49}$ The colonial framing of acceptable forms of Hinduism influenced local sensitivities toward erotic themes in Hindu art. Many highly-placed Hindus so admired their colonizers that, in a kind of colonial and religious Stockholm syndrome, they swallowed the Protestant line themselves and not only gained a new appreciation of those aspects of Hinduism that the British approved of (the Gita, the Upanishads), but also became ashamed of those 
aspects that the British scorned (erotic sculptures on temples, temple dancers). Following the British lead, these Hindus largely wrote off the dominant strain of Hinduism that celebrated the passions of the gods. ${ }^{5}$

While tensions between different orientations in Hinduism predated colonial rule, the new $19^{\text {th }}$ - and $20^{\text {th }}$-century sensitivities toward nudity clearly arose in a context in which European ideas about morality, development, and civilization influenced discussions among Hindus about religious and political identity. New notions of »Indian tradition« and "progressive development« informed the reconceptualization of Hinduism as a single uniting cultural and political force. The sociologist Dev Pathak identified three main factors leading to the rise of unified Hindu politics in colonial and postcolonial India (personal conversation, 2013). First, the British denigration of certain Hindu practices created a sense of collective victimhood. Second, impressed by the political force of the more centralized religious structures of Christian and Islamic organizations, numerous Hindus supported the transformation of the diverse Hindu Dharma into a united religion. A centrally organized Hindu body would not only be valued by the British as a more »civilized « religion, but could also become a political force in independent India. Third, a united Hindu political power could project the image of India as the »Hindu nation« and protect what was perceived to be an ancient and sacred civilization. The politics of Hindurastra (all Hindus in India unite), in other words, was based on a complexity of feelings: hurt pride, wanting to be like the oppressor, and a wish for power and independence. In Pathak's view, Doniger's book was perceived as a threat because she maintained that Hindus are not one and that hierarchical Hinduist structures tend to suppress certain voices. ${ }^{\text {II }}$ 


\section{Debating the Indian constitution: Secularism or pseudo-secularism?}

The controversies over Doniger's interpretations of Hindu texts and images have to be set against the background of struggles for political influence and the control of public space in India. The struggles reflect not only disagreements about the character of the »Indian nation, «but also differences of opinion about the legal foundations of the Indian state. When the British Raj was dismantled in 1947 and two independent states, Hindu-majority India and Muslim-majority Pakistan, were established after partition, the Pakistani constitution defined Pakistan as a Muslim state, adopting Sharia law and allowing only Muslims to become heads of state. By contrast, the Indian constitution was founded on the basis that the state would be »equidistant from all religions - refusing to take sides and having a neutral attitude towards them. ${ }^{52}$ In this secularist system, heads of states could have any religious background, or none at all, and the state promoted the right to religious freedom. Working together with different religious communities, the government would ensure the rights to specific forms of worship and social organization and adopt laws if necessary. As noted earlier, the legal system also meant to protect citizens of all religious backgrounds against activities the court deemed to be offensive.

As the economist Amartya Sen has argued, this system was radically different from the one in Pakistan, where the legal system was directly informed by a singular religious framework and blasphemy laws were applicable only to Islam. In the Indian system, by contrast, the state responded to the social and religious requirements and the religious sensitivities of all religious groups. 
Not surprisingly, legal rulings and court decisions based on the requirements of specific religions were closely scrutinized by the other religious groups. And the historical foundation of the secular system was criticized. Sen has distinguished various »lines of argument « that characterize critical evaluations of Indian secularism by different groups, some of them relating to demands for the withdrawal or destruction of particular material objects. ${ }^{53}$ Most relevant to the case that is central to this chapter are four arguments made by specific Hindu groups: first, that throughout history, Muslims have failed to identify with India and, whenever possible, have destroyed Hindu cultural heritage; second, that the Indian constitution has established a system that favors Muslims, giving them certain rights and privileges; third, that, as the most widespread religion, Hinduism must be accepted as a force of political unity; and fourth, that India is culturally a Hindu country, implying that Hindu religious traditions should have special status and that blasphemy laws should primarily protect Hindu communities..$^{54}$

The term "pseudo-secularism« was specifically used to criticize the government for having instigated special religion-based policies and laws 5 and to attack the National Congress for failing to support Hindu victims of Muslim violence in Kashmir. As Leela Fernandes ${ }^{56}$ argued, this critique became increasingly widespread and forceful with the rise of Hindu nationalism in the 1980 s and the $1990 s^{57}$ as the $»$ rhetoric of rescuing secularism from pseudosecularism « resonated with a strong wish among the broader middle class to: $»[\ldots]$ rescue Indian democracy from the corruption, patronage, and special interests of rising politically assertive subaltern groups that diverged from middleclass models of citizenship and civic and political life. ${ }^{8}{ }^{8}$ As already noted, accusations of pseudo-secularism were also made against Indian supporters of 
Doniger's publications, focusing on their supposed disrespect for sacred »Hindu « culture and religion. The following quote refers to her book $\mathrm{On}$ Hinduism (2013), ${ }^{59}$ published after The Hindus. An Alternative History, a second publication that was withdrawn from sales in India, this time by the Aleph Book Company. Dina Nath Batra, who had led the attack on Doniger's alternative history of Hinduism, publically stated that On Hinduism was »malicious and offending « and that the author had »used derogatory terms for Hindu deities, which hurts the sentiments of devotees. « He added that the book was

[...] part of a conspiracy hatched by »pseudo secularists « to tarnish the image of Hindu culture and India [...]. It is part of a conspiracy hatched by the children of (Karl) Marx and (Thomas) Macaulay to tarnish the image of Hindu culture. There are certain pseudo secularists who are behind this conspiracy. ${ }^{60}$

The reference to Thomas Macaulay (1800 - 1859) was intended to paint Doniger's Indian supporters as uncritical, unpatriotic beings, prejudiced in their judgments by a colonial mindset. Macaulay had played a major role in the introduction of English as a compulsory language in the Indian educational system in the $19^{\text {th }}$ century. ${ }^{61}$ The aim had been to create an Anglicized elite whose members would support British rule and act as middlemen between the colonial rulers and the uneducated Indian masses. Hindu nationalists have argued that Hindu cultural heritage has been under threat from the devastating effects of colonial brainwashing through pseudo-secular policies, ${ }^{62}$ in other words, that the drive for secularism is in fact a false cover for sections of the dominant elite to 
undermine the »true« Hindu foundations of Indian society by »wrongly« diluting its importance to just one religion among many. Ironically, however, the legal system on which the secularist state was founded included section 295A that, as Viswanath claimed earlier, generally worked in favor of Hindu elites.

\section{Public space, religion, and art: Sites of political struggle}

The Indian sociologist P. Radhakrishnan has argued that cultural heritage battles in India have often been caused by power-hungry politicians and religious leaders from all major religious groups who aim to control the public space, thereby creating division and social strife. Addressing the need for a properly functioning Indian secularist system, he has argued that politicians, academics, and journalists should do more to discourage faith-based politics and $»$ reconcile to the needs of modernity. ${ }^{63}$ Commenting on spatial aspects of anti-secular politics, he warned: "The politics of religion has resulted in the mushrooming of religious structures - not so much out of devotion or for worship as for competitive communalism in the public sphere. This is true among Hindus, Muslims and Christians. ${ }^{64}$

Focusing on Hindu spatial politics, Jaffrelot was equally critical of the politicization of public sensitivities around religious sites, stating that disputes about the fate of sacred artifacts and sites have been deployed as political weaponry during elections. ${ }^{65} \mathrm{~A}$ telling example of the interplay of politics and religion in Indian public space is the destruction in 1992 of the Babri Mosque in Ayodhya by hardline Hindu groups, who claimed that the $16^{\text {th }}$ century Moghul 
mosque had been built on the site of an earlier Hindu temple that marked the birthplace of Shri Ram, a major Hindu god. ${ }^{66}$ Another example is the furore generated by plans to build a bridge between India and Sri Lanka on the undersea ridge between Rameswaram and Sri Lanka, at a location claimed to be a sacred Hindu site. ${ }^{67}$

Other complaints against offensive objects in public space have occurred in contemporary art settings. A well-known example is the outrage caused by a painting by the artist M.F. Hussain that depicted the map of India in the shape of a nude Hindu goddess. As discussed by Monica Juneja in this volume, the Muslim painter received death threats from Hindu groups and was subsequently forced into exile. Like Doniger, he was accused of an inappropriate, sexualizing approach, and his work was deemed sacrilegious. Another case of outrage caused by images of sacred nudity occurred in 2007 , when an art exhibition hosted by graduating art students at the Maharaja Sayajirao University of Baroda displayed works by Chandramohan Srilamantula leading to the artist's arrest. The website of the Indian Rationalist Association condemned the attack, reporting, »Though the exhibition was not public, but meant for internal assessment of the art students only, Hindu fundamentalists barged into the Fine Arts faculty and vandalised art exhibits of gods and goddesses. The artist was personally attacked and beaten up. ${ }^{68}$ On this occasion, both Hindus and Christians raised objections. One of the works depicted a nude goddess Durga holding a trident and using it to attack a baby emerging from her womb. A second work by the same artist showed a naked Jesus crucified above a toilet. In an angry report, university authorities objected to the works, describing the latter as: 
[...] a huge Christian Cross where Lord Jesus Christ was shown with his penis out on the Cross, his palms and feet hanging from the two sides and the bottom of the Cross, respectively. Semen was shown as dropping out of his penis into a real toilet commode placed beneath the Cross. The toilet contained fishes. ${ }^{69}$

The staff of the Fine Arts faculty replied with contempt, stating that the writers of the report were clearly »visually illiterate « and that it was »appalling that [they] would indulge in such paraphrasing of works of art and would offer such crude and obscene readings of the images concerned. $\aleph^{70}$ Referring to the painting of Durga, they explained that it had to be read symbolically and that the art student had meant to raise awareness of the crime of feticide. In an interview with The Hindu, Chandramohan Srilamantula defended himself, saying that his aims had been »to show the purity, truth and reality in human beings using the images of god and goddesses. I did not mean to hurt anybody's sentiments. «7 In defense of the image of Jesus on the Cross, his teachers argued,

The work is not figurative but symbolic. It can be interpreted to mean several things: one among them could be that the suffering of Christ on the cross has led his body to a condition of utter dissolution, turning Him into a fleshless state symbolized by water (fluids of the body). As his body drains into a receptacle (a modern commode) it takes its form as new life of elementary creatures [...]. In fact, the theme of water flowing out from the body of Christ after his crucifixion by those who disapproved of his ideas is mentioned in the Bible and is a revered part of the story 
that is read out in churches all over the world at the remembrance of his death that takes place each year on Good Friday. Also the themes of suffering, sacrifice and regeneration are key themes in most world philosophies and religions. ${ }^{72}$

The justification suggested that image producers must be held accountable for the emotional effect of their products only when their work is purposely meant to trigger ill feelings. In other words, the assumption was that the intended use of symbolic imagery took the sting out of any immediate visual affront the artifacts might cause before more abstract reflection. As is already clear from the discussion about the reactions to Doniger's book, such semiotic approaches to art deny the fact that objects not only have changing meanings, but also changing appeal and emotional impact as they are appropriated by different groups and redisplayed in different times and socio-spatial settings. ${ }^{73}$

\section{Digital connections: Interlinked affective spaces}

As the analysis has already illustrated, in an era of globalization, geographic spaces are connected by the movement of people, objects, and ideas. Translocal connectivity is intensified in a digital age in which texts, photographs, and other pictures can be disseminated across the globe in an instant, granting geographically dispersed individuals access to the same materials. This allows virtual communities to unify around them. For example, the bloggers behind binduexistence.org, who uploaded and circulated the anti-Doniger poster reproduced 
in figure 5 , called on other Hindus to share their thoughts and feelings through textual and visual materials: »Let us join hands to empower this blog as a new dimension to create a solidarity in Global Hindus. Hindus from everywhere please send reports and pictures about our status. This blog is yours. «74

The distribution through the Internet of photographs of anti-Doniger demonstrators also exemplified this process (Fig. I). One of the organizations that reproduced the pictures was again the weekly publication Organiser, which often stresses its global readership in places "all over India and Overseas. «75 On its website, Organiser describes itself as:

[...] one of the oldest and most widely circulated weeklies from the capital, [that] first hit the stands in 1947, a few weeks before Partition. Edited and enriched by eminent personalities like A.R. Nair, K.R Malkani, L.K. Advani, v.P. Bhatia, Seshadri Chari, R. Balashanker and now Prafulla Ketkar [...] to name but a few, ORGANISER has come to believe that resistance to tyranny is obeisance to God. ${ }^{76}$

The reference to God and the need to resist »tyranny« alluded to Hindutva ideology, defined as "SERVICE to the Motherland and a sense of dedication to the nation coupled with true secularism. «77 As opposed to the "pseudo-secularism « discussed earlier, »true secularism« aimed to promote a unified Hindu-centric conceptualization of Indian history and identity. Using capitalized script to add a sense of urgency, the weekly laid claim to being a powerful voice that had never given up fighting against injustice faced by Hindus..$^{-8}$ The controversies around Doniger's works were also reported in its online edition. In an interview 
with Nanda, Batra claimed »the intention of Wendy Doniger [was] to mollify Hinduism by bringing out exaggerated sex prevailing in Hinduism. « ${ }^{79}$

The Internet was not only a powerful tool for India-based Hindutva supporters to reach Hindus around the world, but was also used by Hindu immigrants in the US to discuss the academic interpretation of Hinduism in their country of residence. On February 17, 2014, Arthur J. Pais, editor of the online publication Rediff.com and the India Abroad newspaper, published an interview with Rajiv Malhotra, entitled When Westerners make fun of our gods, they're instigating trouble. ${ }^{80}$ Malhotra argued that books by Wendy Doniger, Jeffrey Kripal, Paul Courtright, and like-minded scholars were problematic because they expressed a »vulgar kind of view « that dominated the academic debate in America. ${ }^{8 \mathrm{I}}$ Defending the destruction of Doniger's book in India, he said:

In theory $[. .$.$] Hindus are very open. I'm one of them. I've coined the phrase$ »open architecture.«But I think the Wendy Doniger group is not allowing open architecture. They are closing this architecture. They are bringing a point of view in such a heavy-handed way that it tends to dominate and it tends to suppress the alternative points of view. So some kind of counteraction is necessary and using the law is a decent thing to do. ${ }^{82}$

He argued that the outrage had »nothing to do with Christianity versus Hinduism, because most of these people are Jewish, anyway. They are using a Marxist lens, a Leftist lens, a Freudian lens. The kind of theories they are using are completely inapplicable to the Indian way of life. $\ll^{83}$ Criticizing Doniger in online statements, interviews, and forums, he claimed that his views »created 
a huge awareness and awakening among the Diaspora and among people in India.« Distributed through printed and digital media, his words inspired audiences in many different locations to join the revolt that eventually led to the withdrawal of her two books. ${ }^{84}$

Malhotra also penetrated the academic realm, being the driving force behind the publication of Invading the Sacred: An Analysis of Hinduism Studies in America, a volume edited by Krishnan Ramaswamy, Antonio de Nicolas, and Aditi Banerjee and published in 2007. It included chapters by contributors based in Europe, the Us, and India, mostly Hindu academics who identified factual mistakes in works by non-Hindu American scholars and fiercely attacked psychoanalytical approaches in Hindu Studies. ${ }^{85}$ The 545 -page volume was published by Malhotra's Infinity Foundation and, aiming for a wide readership, was (and still is) freely downloadable from its website. ${ }^{86}$ In the foreword, S.N. Balagangadhara, Director of the Comparative Science of Cultures Research Centre at Ghent University, stated that »for the first time, [Indian intellectuals, M.s.] will test the Western knowledge of India. ${ }^{87}$ In the preface, Arvind Sharma, Birks Professor of Comparative Religion at McGill University in Montreal, noted that Hindu »insiders [had now started to] claim the right to tell the [non-Hindu, M.s.] outsiders about their faith, thus reversing the flow of information. $\aleph^{88}$ The withdrawal of Doniger's books must also be understood in this wider context of re-appropriation. ${ }^{89}$

Doniger did not, however, give up so easily. After failed attempts by John Makinson, Chair of Penguin Random House, to republish the book in India, former Penguin India publisher and editor-in-chief Ravi Singh decided to do so through his new company, Speaking Tiger. Singh was the person who had originally 


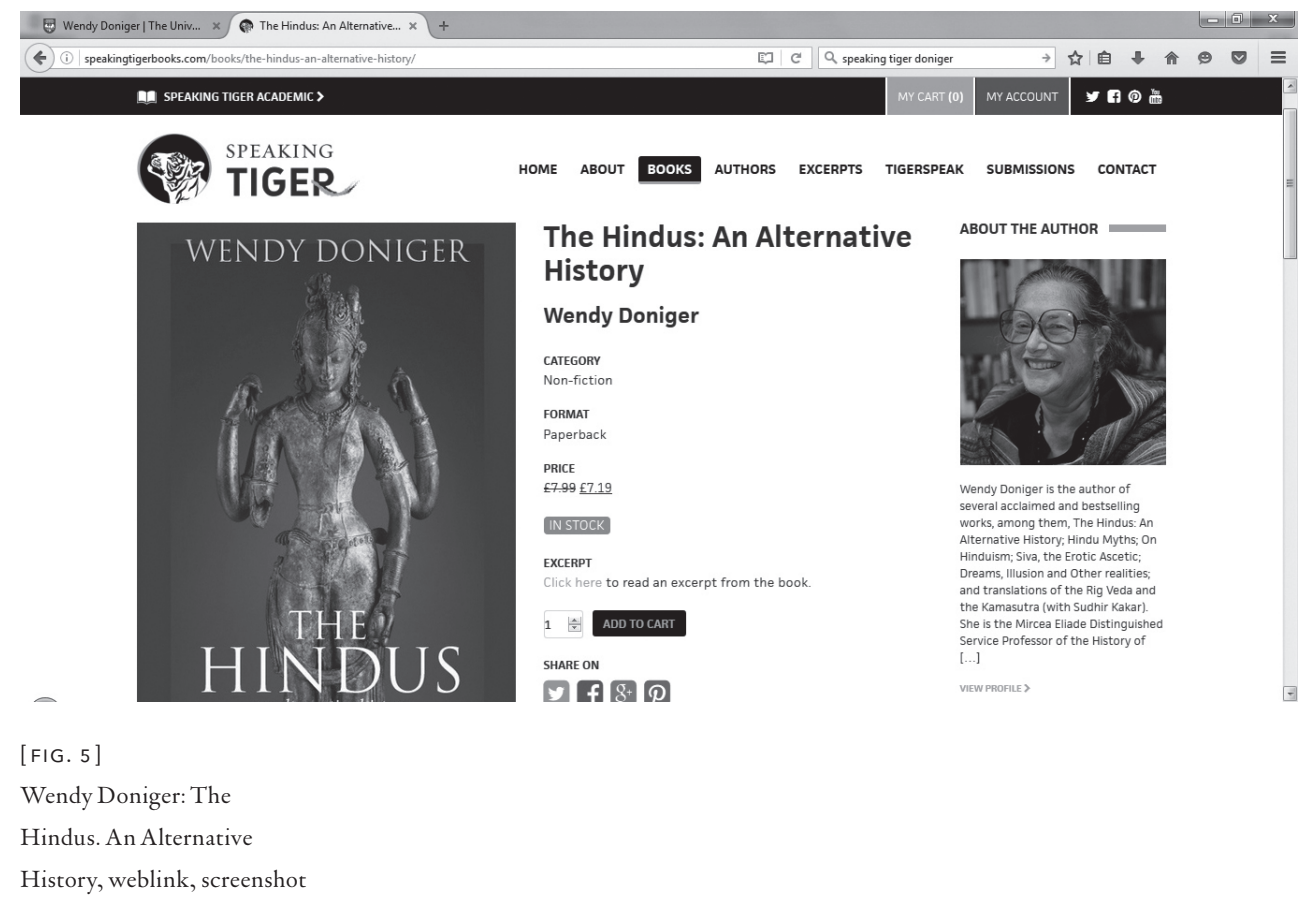

agreed in 2010 to publish Doniger's book and was very supportive of her work. As Doniger triumphantly declared in 20ı6:

[The Hindus. An Alternative History] is now widely available in India, and translations into Tamil and Telugu are also forthcoming. Ravi Singh sets a great example of courage and determination for other publishers. It is possible to publish controversial books in India. Ultimately, the law is made by individuals, and individuals can resist it. ${ }^{90}$ 
Perhaps it is significant, however, that a less provocative image was chosen as cover for the book (Fig. 5).

\section{Conclusion}

This chapter has demonstrated that the study of concrete acts of blasphemy and blasphemy accusations can throw light on complex social, religious, and political processes that are often linked. It showed that the public expression of love or hatred for a particular image can be an important element in the performance of identity, demonstrating loyalty to a specific religious group and/ or political faction. Only an approach that is both historical and spatial, and that focuses on the affective and sensorial aspects of image perception, can demonstrate how fights over the ownership and appropriation of specific representations have political relevance within and across local, national, and transnational social settings.

In the case of Wendy Doniger's books, two opposing views on representational practice defined the debate. On the one hand, Doniger pleaded for an open-ended approach to knowledge production, according to which images, whether visual or textual, could be interpreted in different ways, depending on the aims, outlooks, and experiences of the interpreter. This approach opens up to new critical scrutiny of previously unchallenged or otherwise authoritative interpretations and produces alternative views that may trigger all sorts of emotional reactions, from joy and admiration to anger and moral outrage.

By contrast, her fiercest critics appealed to their religious birthright and their own experiential sense of truth, ideologically framed as faithful Hindu 
practice. To them, there was only one acceptable interpretation of Hinduism, encoded in the ideology of Hindutva. Alternatives were perceived as hurtful, disrespectful, and polluting the sacred realm. Exposure to such sacrilege evoked strong feelings of anger that were given public airings as displays of moral and political outrage. As part of this ideological drive, Hindutva adherents expressed the belief that any object considered sacrilegious or offensive could itself be appropriated as a misused religious object that required destruction. In other words, rather than discounting offensive artifacts or texts as ill-informed nonsense not worthy of discussion, the fact that they contained illustrations of sacred Hindu texts or deities inspired Hindutvans to take possession of them, in order to safely dispose of them. Section 295A, a piece of legislation that reinforced the discourse of »hurt religious feelings, « framed their actions.

Ironically, while the opponents of Doniger based part of their arguments on the idea of Hindu exceptionalism within Indian society, they sought to extend their reach and political influence beyond India by means of virtual communities that united the Hindu diaspora around the globe, seeking in particular to enlist the aid of Indian scholars in Western institutions. Their arguments against Doniger were based not only on alleged misinterpretation or alleged historical error, but also on the idea that the correct interpretation of the religious sphere required an a priori knowledge of what it is to be one of the faithful. When the publishers agreed to destroy the book and to not sell other Doniger works in India, secularists feared that this would set a dangerous precedent that could intimidate other publishers, artists, or critics into submitting to the vociferous attacks of Hindu religious groups and the threat of legal action. With the rise of Hindu nationalist politics, supported and encouraged by the groundswell of 
Hindutva support, secularists also feared that, should such »victories« ever be upheld in court, decisions on what is deemed offensive enough to warrant a ban under the Indian penal code protecting religious harmony might henceforth be decided not by scholars, politicians, or academics, but by the aggrieved religious groups themselves. If the law officially acknowledged that such groups enjoyed the authoritative understanding of Hinduism and its texts and symbols, then it would effectively be granting them a monopoly on how texts, symbols, or artifacts containing any Hindu religious reference should be used or exhibited in much wider cultural contexts, whether that be in art exhibitions, festivals, or even advertisements.

Given the extremes to which such a precedent could be taken, the Doniger case became a much wider topic of debate among both scholarly and non-scholarly sections of society. This debate, however, is not new. Both before and after partition, Hindutvans sought to further entrench their version of Hinduism as the cultural bedrock of Indian society and felt that blasphemy laws could be used as a way of ennobling Hindus and raising Hinduism above the ranks of other competing religions. The reappearance of The Hindus. An Alternative History on the Indian market showed, however, that such laws are not always effective.

1 Wendy Doniger: The Hindus. An Alternative History, Oxford 2009 .

2 Pramod Pathak: Wendy's unhistory making history; Quote from the online publication site Organiser, http://organiser.org/Encyc/2014/3/18/Wendy\%E2\%80\%99s-unhistorymaking-history. aspx? $\mathrm{NB}=8 x$ lang $=4 \& \mathrm{mI}_{\mathrm{I}}=8 \mathrm{~m} 2=8 \mathrm{xp}=8 \mathrm{Pp} 2$ $=\& \mathrm{p} 3=\& \mathrm{p} 4=\&$ PageType $=\mathrm{N}$ (accessed Feb. 1०, 2015). 
3 In this context, »image « refers to both image types, for example, the mental image of »Ganesh «, and to artifactual and digital appearances - a statue, picture, photograph, or digital representation of Ganesh, or a textual description printed on paper.

4 https://divinity.uchicago.edu/wendy-doniger, linking to https://www.youtube.com/watch?v=how-wI-Gxj4, (accessed on April I, 2016).

5 Devdutt Pattanaik: Interviewing Wendy Doniger, http://devdutt.com/articles/myth-theory/my-interview-with-wendy-doniger.html (accessed May 2, 2016).

6 In India, Pattanaik is widely known for writing contemporary mythological bestsellers that are available in English, which makesthemhighlyaccessible to Hinduslivingabroad. I remember seeing his best-selling books on Hindu iconography in 2011 in the Chennai airport bookshop. He writes for both children and adults, publishing titles such as Pasbu: Animal Tales from Hindu Mytbology and The Success Sutra, the latter being advertised as a book »packed with unique and profound insights into how individuals can create wealth and achieve success in life by following Indian principles of strategic think-ing and decision-making (http://devdutt.com/category/books). These popular genres represent Hindu ideas in quite different ways and to quite different audiences from Doniger's Hinduism: An Alternative History.

7 Devdutt Pattanaik: Interviewing Wendy Doniger, (see note 5). Malhotra, one of Doniger's fervent critics, quoted a passage from Harvard-based Diana Eck's 2001 book on »new religious America« to accuse Doniger of promoting cross-religion misunderstanding. »Christians look at the Hindu worship of the linga and see it as phallic worship, while Hindus look at the Christian sacrament of communion and are repulsed by its symbolic cannibalism.« (Eck, quoted in Invading the Sacred Year: 71, see further discussion below).

8 Brian K. Pennington: The Unseen Hand of an Underappreciated Law. The Doniger Affair and Its Aftermath, in Cynthia Eller, Tammi J. Schneider (eds.): Journal of the American Academy of Religion, 84/2 (2016), pp. 322-336, here p. 326 .

9 Devdutt Pattanaik: Interviewing Wendy Doniger, (see note 5$)$.

${ }^{10}$ See, for example, the contributions to Øivind Fuglerud/Leon Wainwright (eds.): Objects and Imagination. Perspectives on Materialization and Meaning, Oxford 2015, and contributions to Maruška Svašek / Birgit Meyer: Creativity in Transition. Politics and Aesthetics of Cultural Production Across the Globe; in Brian K. Pennington: The Unseen Hand (see note 8). Pattanaik identified practices of political opportunism, religious intolerance, and scholastic puritanism as factors shaping questions of property and propriety with regard to Hindu imagery.

${ }^{11}$ For a more in-depth discussion of my conceptualization of »aestheticization « and to explore this process, see Maruška Svašek: Anthropology, Art and Cultural Production, London 2007 and Maruška Svašek: Aestheticisation and the Production of Religious Space in Chennai, in Alexandra Grieser / Jay Johnston, (eds.): Aesthetics of Religion. A Connective Concept. Amsterdam: DeGruyter (forthcoming in 2017).

12 Svašek/Meyer: Creativity in Transition (see note 8); See also Patricia Spyer/Mary Margaret Steedly: Images that Move, Santa Fe and New Mexico 2013

${ }^{13}$ Richard H. Davis: Lives of Indian Images, Prince-ton/N.J. 
1997, p. 9.

14 Svetlana Alpers: The Museum as a Way of Seeing, in Ivan Karp/Steven D. Lavin(eds.): Exhibiting Cultures. The Poetics and Politics of Museum Display, Washington D.C. I99I, Pp. 25-32.

15 Davis: Lives of Indian Images (see note 13), p. 25.

16 See also Amit Desai / Maruška Svašek: Transvisionary Imaginations. Artistic Subjectivity and Creativity in Tamil Nadu, in Fuglerud/ Wainwright (eds.): Objects and Imagination (see note Io), pp. $207^{-229}$

17 When I asked their teacher whether he sometimes looked with a similar studious, artistic eye at the sacred statues of Hindu gods and goddesses inside the sanctum sanctorum of the temple, he did not speak, but stared back at me, first puzzled, then with a slightly amused expression. Worship through ritual engagement with the divine within the temple walls through darshan required a very different perceptual and affective engagement. »Darshan, translated literally from Sanskrit as >seeing and being seen by God, is that moment when the worshipper is receptive to recognition by the God or Goddess«; Stephen P. Huyler: Meeting God. Elements of Hindu Devotion. New Haven 1999 , p. 36 .

Numerous authors have explored these dynamics and investigated the often-uneasy relations among art, religion, politics and heritage. See, for example, Bruce M. Sullivan: Sacred Objects in Secular Spaces. Exhibiting Asian Religions in Museums, London 2015; John Henry Merryman: Thinking about the Elgin Marbles. Critical Essays of Cultural Property, Art and Law, Alphen an den Rijn 2009; John A. Walker: Art and Outrage. Provocation, Controversy and the Visual Arts, London 1999; James Noyes: Politics of Iconoclasm. Religion, Violence and the Culture of Image-Breaking in Christianity and Islam, London 2013. Spyer / Steedly: Images that Move (see note 12 ), 2013 .

${ }^{19}$ http://cis-india.org/internet-governance/resources/section-295a-indian-penal-code (accessed on May 20, 2016).

${ }^{20}$ As Pennington noted, "The suit charged Doniger and Penguin with two violations of sections 153 and ${ }_{153} \mathrm{~A}$, which criminalize causing enmity between religious communities (most cogently for the book's alleged claims that organizations on the Hindu right, such as the Rashtriya Swayam Sevak Sangh, are >against $<$ Muslims and Christians); and it also accuses them in a general way of violating sections 298 and 505, which outlaw statements intended to offend religious persons or promote enmity between religious communities [...]. The weight of the legal case, however, was borne by section 295A. Batra cited violations of section ${ }_{295} \mathrm{~A}$ three times in a general and summary fashion in the lawsuit's concluding sections, building there on his prior charges that Doniger and Penguin contravened the law on five specific counts. First, he argued that Doniger violated the code by calling the epic The Rāmāyaṇa a swork of fiction< (claim $2 \mathrm{I}$ in the legal filing). Second, he condemned Doniger's insinuation that the epic's heroine, Sita, had sex with the brother of Rama (her husband and the paradigmatic righteous king for Hindus) as >pure and total blasphemy< (claim 23). Third, he noted that in the 198I Penguin edition of the Rig Veda Doniger had translated verse I0.85.13 to call for the sacrifice of $>$ cattle, $<$ but translated the same word >cow< in The Hindus, displaying a >deliberate, malicious and conscious intention to outrage religious feelings of millions of Hindus because, the suit alleges, >cattle< can include goat, buffalo, or deer (claim 29). Fourth, he charged that in characterizing the sun god Surya's impregnation of Kunti- the mother of the five Pandava brothers who are the heroes and kings of India's other great epic, the Mahābhārata_as a >rape, < Doniger deliberately and 
maliciously misconstrued $>$ divine blessings for birth of children (claims 33-34). Finally, he alleged that the selection of the artwork for the book cover, which depicted, in the suit's language, ,Lord Krishna... sitting on buttocks of a naked woman surrounded by other naked women, < was tantamount to invading the sacredness attached to Sri Krishna (claim 35) (Arora 2010). Brian K. Pennington: The Unseen Hand (see note 8), pp. 326-327. Emphasis added. See also Monika Arora: »Sh. Dina Nath Batra Send Legal Notice to Wendy Doniger.«, http://www.bharatiyashiksha.com/2010/04/I4/sh-dina-nath-batra-send-legal-notice-to-wendy-doniger (accessed on Feb. 6, 2017).

${ }^{21}$ Maria Misra: Vishnu's Crowded Temple. India Since the Great Rebellion, New Haven 2007, p. 169

22 Ibid., p. 167

${ }^{23}$ Ibid., p. 170.

${ }^{24}$ Wendy Doniger: A Response, in Journal of the American Academy of Religion, 84/2 (2016), pp. 364-366, here p. 365 .

${ }^{25}$ Pennington pointed out, »Whereas reactions in the United States tended to place the controversy in the context of recent clashes between the Hindu right and western academic books by American authors Kripal, Courtright, and Laine, responses by both Indian media and the Hindu diaspora in the United States framed it in reference to the 1988 ban on the import of Salman Rushdie's Satanic Verses by the government of India and the 201 removal of A. K. Ramanujan's essay, 'zoo Rāmāyaṇas: Five Examples and Three Thoughts on Translations from the Delhi University syllabus for the History B.A.«At the same time, »Indian reactions, that is, tended to see the episode as one moment in an ongoing battle within India itself, but reactions from within the United States tended to lay blame on the Indian social and intellectual environment as such.«
Pennington: The Unseen Hand (see note 8), p. 328.

${ }^{26}$ http://www.ndtv.com/videnews/the-social-network/whyno-wendy-doniger-over-chai-30931I (accessed on May 20, 2016)

${ }^{27}$ https://www.youtube.com/watch?v=YAgy7woLJGs (accessed on June 2, 2016).

${ }^{28}$ She spoke at a time when the BJP (Bharatiya Janata Party) was rapidly gaining support and alluded to the increasing influence of Hindu nationalist groups in the realm of Indian politics. Led by Narendra Modi, the BJP (»Indian People's Party «) secured a majority of 282 seats during the general election in 2014. The BJP was founded in 1980 and is widely regarded as a ring-wing party that has organizational and ideological links to the Hindu nationalist Rashtryia Swayamsevak Sangh (RSS).

${ }^{29}$ The Guardian, I3 February 20I4. Penguin's withdrawal of The Hindus causes international outcry https://www. theguardian.com/books/20I4/feb/13/penguin-withdrawal-hindus-arundhati-roy-neil-gaiman (accessed on June I, 2016). See also Andrew Buncombe: Arundhati Roy criticises Penguin for pulping The Hindus: An Alternative History, in The Independent Feb 13, 2014. http://www.independent.co.uk/arts-entertainment/books/news/arundhati-roy-criticises-penguin-for-pulping-the-hindus-an-alternative-history-9126247.html (accessed on June I, 2016).

${ }^{30}$ Rushdie was accused of blasphemy when his novel was published in 1988 in the UK, and a year later, the Iranian Ayatollah Khomeini of Iran ordered Muslims to kill the writer. Rushdie had to go into hiding, and a moral »war ensued between supporters of freedom of speech and defenders of the right to take revenge on people committing sacrilege. 
31 In response to the withdrawal of Doniger's book, the Indian branch of the writers' organization PEN agreed that »the removal of books from our bookshops, bookshelves, and libraries, whether through state-sanctioned censorship, private vigilante action, or publisher capitulation are all egregious violations of free speech that we shall oppose in all forms at all times « in The Guardian (Feb I3, 2014).

32 A practicing Hindu who is also influenced by Buddhism.

33 Andrew Buncombe: Arundhati Roy criticises Penguin (see note 29).

34 This organization had shortlisted Doniger's book for an award in 2009 .

35 The Guardian, Feb. 13, 2014: Penguin's withdrawal of The Hindus causes international outcry.

${ }^{36}$ Wendy Doniger: A Response (see note 24), p. 364.

37 Pennington: The Unseen Hand (see note 8), p. 237, quoting (anonymous) »Penguin India's Statement on ’The Hindus by Wendy Doniger«, February. Penguin Books, India. Available at http://www.penguinbooksindia.com/en/node/4090.html (accessed on Feb. 7, 2016).

${ }^{38}$ The Guardian, Feb. 13, 2014: Penguin's withdrawal of The Hindus causes international outcry, https://www.theguardian.com/books/2014/feb/13/penguin-withdrawalhindus-arundhati-roy-neil-gaiman (accessed on Jan. IO, 2016).

39 The Guardian further reported, »The historian [William] Dalrymple agreed, saying the real villains are the laws in this country, which were old colonial laws drawn up in the 1890 s, and which make insulting religion a criminal offence $[\ldots]$. (see my question at the end) $>$ They give the general impression we are in 1936 in Germany, with freedoms being curtailed on a daily basis,« said Dalrymple, author of Nine Lives: In Search of the Sacred in Modern India, The Last Mughal, and White Mughals. 'The reality is that it is very difficult to defend yourself because the law is stacked very heavily on the side of any lunatic. It's shocking, appalling, dreadful and entirely negative, but I can understand why Penguin did what it did. They should have defended it, but I can understand why, with the law as it is, they decided they couldn't win the case.« The Guardian, Penguin's withdrawal of The Hindus causes international outcry. See also Nalin Mehta: Great Indian tradition of debate alive and well: Wendy Doniger, in The Times of India, Nov. 25, 2015, http://article.wn.com/ view/2015/11/25/Great_Indian_tradition_of_debate_alive_ and_well_Wendy_Donige/(accessed on June I, 2016).

${ }^{40}$ C. S. Adcock: Violence, Passion, and the Law: A Brief History of Section 295A and Its Antecedents, in Journal of the American Academy of Religion 2016 (82)2: 340.

${ }^{41}$ C. S. Adcock: Violence, Passion, and the Law 2016, 34I. See also N. Gerald Barrier: Banned: Controversial Literature and Political Control in British India, 1907-1947, 1974, Columbia, MO: 1907-1947, Columbia, MO 1974; G. R. Thursby: Hindu-Muslim Relations in British India: A Study of Controversy, Conflict, and Communal Movements in Northern India 1923-1928, Leiden 1975; Beyond the >Communal 1920s: The Problem of Intention, Legislative Pragmatism, and the Making of Section 295A of the Indian Penal Code. Indian Economic and Social History Review 50/3 (2013), Pp.317-340.

${ }^{42}$ C. S. Adcock: Violence, Passion, and the Law (see note 4I), p. 345 .

${ }^{43}$ He pointed out, "When and how laws regulating speech are actually enforced depends crucially not only on the 
formal apparatus of the state and its laws, but on complex relations of mutual dependence between official and nonofficial actors, what I have called elsewhere the caste-state nexus (Viswanath 2014). The economy of offense in modern India that I have described reveals that not only the language of hurt sentiments but also the defense of free speech raised against it are misleading. The idea of hurt religious sentiments establishes a false equivalence between the many types of speech that offend members of Indian society; the expressions »hurt sentiments« and »free speech « conceal what in fact determines the limitation of speech in modern India. Social and political dominance, and not an abstract right to have one's religion, caste, or other ascriptive status protected from insult, together impose violent speace on India's most vulnerable citizens. « Rupa Viswanath: Economies of Offense. Hatred, Speech, and Violence in India, in Journal of the American Academy of Religion 84/2 (2016), p. 360.

${ }^{44}$ Pennington: The Unseen Hand (see note 8), p. 331.

${ }^{45}$ https://hinduexistence.org/2014/02/12/success-penguin-to-destroy-copies-of-wendy-donigers-hackneyedthe-hindus-an-alternative-history/ (accessed on June 8, 2016). It declared: »We have to procure and establish our traditional Hindu land in India at any cost and have to ensure dignity and rights of Hindus in every corner in this World. Yes, We have to have Hindusthan in India in its true sense. And do not tolerate persecution upon Hindus in Pakistan, Bangladesh, Malaysia, Fiji, Muslim majority part in India including J\&K, Afghanistan, Various Muslim Countries or anywhere in this World.«

${ }^{46}$ Partha Mitter: Much Maligned Monsters. History of European Reactions to Indian Art, Oxford 1977.

47 A.C. Burnell: The Voyage of J.H. van Lindschoten, London I885, p. 289, quoted by Partha Mitter: Much Malingned
Monsters (see note 46), p. 2I.

${ }^{48}$ Wendy Doniger: From Karma to Karma, in Social Research. An International Quarterly, 78/1 (201I), Pp. 49-74, here p. 64 .

${ }^{49}$ Ibid. In the Protestant moral framework, it was deemed wrong to worship through engagement with any outer reality; real contact with the divine was perceived as an inner, unmediated direct link to God though prayer. Birgit Meyer: How Pictures Matter. Religious Objects and the Imagination in Ghana, in Øivind Fuglerud / Leon Wainwright (eds.): Material Mediations (see note Io), pp I60-I82.

${ }^{50}$ Wendy Doniger: From Kama to Karma (see note 48 ), p. 65.

51 Dev Pathak argued, however, that the idea of a varied, diverse Hindu Dharma including various sects and folk ideas can also be idealized. This glorification of folk Hinduism as a dialogical, flexible field of religious ideas and practices is problematic. The problem is the bifurcation, the opposition of "good « (folk) religion to »bad « (canonical, priestly) religion or vice versa. Ongoing intolerance is partly based on oppositional thinking; instead, it should be acknowledged that there is always a negotiation between the priests and the folk worshippers. Priests do not always follow the canon; ritual-canonical performances have space for folk renditions. The opposition of Great Tradition versus little traditions does not reflect reality. It may be used as a heuristic device, but cannot fully explain reality. In reality, there are always influences. The whole intolerance is sustained by the bifurcation.

52 Amartya Sen: The Argumentative Indian, London 2005 , pp. $295-96$.

${ }^{53}$ Sen, ibid., pp. 297-300, argued that some (especially West- 
ern) journalists reporting on Hindu-Muslim clashes have claimed that Indian secularism is essentially non-existent. Second, some intellectuals in the West and in India have equated »secularism« with »modernism«, arguing that ideologies of progress and modernity have created an intolerant society that has discouraged traditional forms of peaceful coexistence. Third, certain Hindu groups have argued that the Indian constitution has established a system of pseudo-secularism that favors Muslims, giving them certain rights and privileges. A fourth criticism is based on the idea that while there may be a diversity of religious groups in India, Hinduism must be accepted as a force of political unity. The fifth critical argument is that throughout history, Muslims have failed to identify with India and, whenever possible, have destroyed Hindu cultural heritage. The last line of criticism is based on the view that India is culturally a Hindu country, which means that Hindu religious traditions should have special status, and that blasphemy laws should most of all protect Hindu communities.

${ }^{54}$ Ibid., pp. 297-300.

55 These were mainly laws addressing familial matters such as marriage, divorce, inheritance, maintenance, and adoption.

${ }^{56}$ Leela Fernandes: India’s New Middle Class. Democratic Politics in an Era of Economic Reform, Minneapolis 2006 , p. 179 .

${ }^{57}$ At this time, »the urban middle classes $[. .$.$] began to turn$ to the BJP as a party that could represent a strong middleclass oriented nationalist party - one that could provide an alternative to a Congress party that the middle classes viewed as corrupt and captured by subordinate groups.《 Fernandes: India's New Middle Class (see note 56), p. 178 . See also Ashutosh Varshney: Contested Meanings: Indian
National Unity, Hindu Nationalism, and the Politics of Anxiety, in Daedalus I22 (1993) and Ashutosh Varshney: Ethnic Conflict and Civic Life: Hindus and Muslims in India, New Haven 2002. A court ruling in the Shah Bano case sparked a public debate about the nature of democratic politics, and the BJP accused the ruling Congress party of »pander[ing] to conservative Muslim leaders; « see Fernandes: India’s New Middle Class (see note 56), p. 178.

${ }^{58}$ Ibid., p. 179.

59 The publishing company Aleph decided to withdraw the book. Anmol Vellani, the founder and former executive director of the India Foundation for the Arts, commented, "When a big publisher like Penguin withdraws, the smaller ones feel they have no chance at all. Also, the problem is the law and the way in which the lower courts interpret it. Publishers are not even willing to try it in a court of law because the lower courts tend to interpret malicious intent< very loosely. It needs to be reframed so that such a wide interpretation isn't possible. Anjali Muthanna: Is Wendy Doniger being targeted by Indian publishing houses? Mar 6, 20I4, http://timesofindia. indiatimes.com/life-style/books/features/Is-WendyDoniger-being-targetted-by-Indian-publishing-houses/ articleshow/31476544.cms (accessed on June, 22016 ).

60 (my emphasis, M.S.) http://www.rediff.com/news/report/ wendy-doniger-is-now-under-attack-for-on-hinduism/ 20I40301.htm (accessed on June, 2 2016).

${ }^{61}$ He was a Cambridge-trained historian and politician who had become a member of the Supreme Council in colonial India in 1834 . The idea was that the English language would replace Persian and Sanskrit. Various spokesmen of Hindutva organizations, such as the leader of the RSS, H.V. Sheshadri, protested against the »white man's burden, « the ongoing influence of a colonial thinking on the 
self-perception of Indian citizens. Macaulay also drafted the Indian Penal Code that was adopted in all the British colonies and is still used in India today.

62 They have called for a major change in the Indian Constitution, instigating a Uniform Civil Code that will put an end to special provisions for specific religious groups and reconstruct India as a Hindu nation. During the election campaigns, the BJP party leader Narendra Modi its manifesto to draft the code, arguing that it would end gender inequality. In an open letter to the Guardian (April ıo, 20I4), various UK- and US-based writers, artists, and intellectuals, including Anish Kapoor, Salman Rushdie, and Homi K Bhabha, questioned Modi's »moral character and political ethics « and his support for Muslim women. They argued that his failure to take responsibility for anti-Muslim violence in Gujarat in 2002, which »led to the deaths of more than 2,000 men, women and children, "was »incompatible with India's secular constitution, which, in advance of many constitutions across the world, is founded on pluralist principles and seeks fair and full representation for minorities. Were he to be elected prime minister, it would bode ill for India's future as a country that cherishes the ideals of inclusion and protection for all its peoples and communities.« Since the election victory of the Bharatiya Janata Party (BJP) in 2014, the introduction of a Uniform Civil Code has been high on the political agenda. For a fascinating analysis of Modi's campaign strategies and links to Hindutva ideology, see Lance Price: The Modi Effect. Inside Narendra Modi’s Campaign to Transform India, London 20I5, especially pp. 28-31.

63

3 »In a country where democracy and secularism are still nascent in the minds of its unwashed millions and pale before faith, what the pillars of democracy-legislature, executive and judiciary - the intelligentsia as class, and the media at large should do is to wean people away from peripheral and superficial aspects of faith, and faith-based politics through systematic inculcation of and pragmatic approach to diversity and development. P. Radhakrishnan: Crossing the Sethu Rubicon, in The New Indian Express, 2007, p. I, cited in Prasant Kumar Trivedi (ed.): The Globalization Turbulence. Emerging Tensions in Indian Society, New Delhi 2011, p. I85.

${ }^{64}$ Ibid.

65 »Hindu nationalists cultivate the art of being outraged when elements of their religion are affected. They promptly denounce attacks against sacred symbols of Hinduism: any disrespect can be portrayed as blasphemy and lay itself open to popular mobilizations - which may translate into votes. Christophe Jaffrelot: Hindu Nationalism and the (Not So Easy) Art of Being Outraged. The Ram Setu Controversy, in Samaj. South Asia Multidisciplinary Journal 2 (2008), https://samaj.revues.org/1372 (accessed on June I3, 2016). See also Christophe Jaffrelot: Religion, Caste and Politics in India, Chennai 2010.

${ }^{66}$ In 2010, the Allahabad High Court ruled that the disputed site should be divided into three parts, controlled by two Hindu groups and one Muslim group. See also Peter van der Veer: Religious Nationalism Hindus and Muslims in India, Chicago 1997.

${ }^{67}$ Radhakrishnan has strongly criticized such activities, arguing that religious concerns should make way for the need to economically develop. »We cannot afford anymore to live in the past and the present simultaneously, and if there are roadblocks on our paths to development which are not of vital concern to the nation, we ought to remove them and keep going. It is from this perspective that the Rama-Sethu row should be understood. The issue is not one of faith but of development. Those who genuinely believe Rama as real, as divine, as an avatar, and who should continue to be revered and worshipped, already have 
a surfeit of sites and structures in different parts of the country.« Radhakrishnan: Globalization, Faith and Development Politics (see note 63), p. 186

${ }^{68}$ http://www.rationalistinternational.net/article/2007 /20070518/en_4.html (accessed on July Io, 2016).

${ }^{69}$ Shubhajit Roy: MSU Faculty sends lesson to V-C on art: your reading »obscene, illiterate, « in The Indian Express, May 30, 2007, http://archive.indianexpress.com/news/ msu-faculty-sends-lesson-to-vc-on-art-your-reading--obscene-illiterate-/32351/(accessed on Feb. 2, 2016).

${ }^{70}$ Ibid.

${ }^{71}$ Gollapudi Srinivasa Rao: My aim is to show purity, reality in human beings, in The Hindu, May 24, 2007.

72 Roy: MSU Faculty sends (see note 69).

${ }^{73}$ Maruška Svašek: Anthropology, Art and Cultural Production, London 2007. Maruška Svašek: Moving Subjects, Moving Objects, Oxford and New York 2012

${ }^{74}$ https://hinduexistence.org/2014/02/12/success-penguin to-destroy-copies-of-wendy-donigers-hackneyed-the-hindus-an-alternative-history/ (accessed on June 8, 2016).

75 The weekly claims to have widespread national and international readership, including »thinkers, writers, opinionmakers, legislators, members of both the Houses of Parliament, editors of dailies and other periodicals, « as well as readers in »UK, USA, Canada, and 54 other countries of the world, «http://www.organiser.org/static/about.aspx (accessed on Feb. 10, 2015).

${ }^{76}$ Ibid.
77 This ideology was also expressed by the inclusion of a quote from Gowalkar, an influential activist, who once said, $»$ For clear, straightforward, impartial views on subjects of national and international importance and for imbibing unadulterated patriotism, it is useful to read organiser. It will fulfill the expectations for correct guidance in all current affairs.«Ibid.

78 »Repeated attempts to muffle its voice and the motivated opposition to it by some powers did not succeed.« Ibid.

${ }^{79}$ Ibid.

${ }^{80}$ http://www.rediff.com/news/slide-show/slide-showI-when-westerners-make-fun-of-our-gods-theyre-instigating-trouble/20140217.htm (accessed on Dec. 20, 2015).

${ }^{81}$ He complained that in the US, hardly any practicing Hindus were invited to academic conferences on Hinduism. Most speakers were non-Hindus who had learned Sanskrit and presented their own interpretations of Hindu practices and belief. In his view, »Many of the Hindu leaders in this country (America) maybe were too arrogant, too cocky, or too embarrassed or too scared to talk about it. They did not think it was important to take any action.«

${ }^{82}$ http://www.rediff.com (see note 80).

${ }^{83}$ Ibid.

${ }^{84}$ He claimed, "So many other groups started getting immersed and started taking up my cause and they are the ones who started litigating on Doniger and her book and so on in India.« He noted, »It was entirely non-Hindus who felt that they have understood the text, learnt Sanskrit and they were able to interpret it. So, I felt that this is a huge untold story. I started writing articles. These articles created a huge stir. And, this is the situation with these 
people. We compiled these arguments in a book called Invading the Sacred that came out in 2007 , and since then I have come out with three more books that are not on Wendy but other issues related to Indian civilisation and Indian philosophy and thought and so on. I personally moved on beyond Wendy Doniger. But I have created a huge awareness and awakening among the Diaspora and among people in India. So many other groups started getting immersed and started taking up my cause and they are the ones who started litigating on Doniger and her book and so on in India.« Ibid.

${ }^{85}$ The book also incorporated quotes from scholars of Hinduism from across the globe, for example citing the cultural historian and Indologist Hans Bakker who had objected to »[f]ast-food-like publications designed to attract attention, readership and sales « that are »devoid of meticulous scholarship or authenticity«. Hans T. Bakker: The Skanda Purana, Volume I, Groningen, 1998, quoted by Pandita Indrani Rampersad: Exposing Academic Hinduphobia, in Krishnan Ramaswamy / Antonio de Nicolas / Aditi Banerjee (eds.): Invading the Sacred: An Analysis of Hinduism Studies in America, 2007 , p. 7 I.

${ }^{86}$ See http://rajivmalhotra.com/books/invading-sacred/ (accessed on Feb. 6, 2017).

${ }^{87}$ He added, "This has not happened before; it will happen for the first time. Generations of Indian intellectuals have accepted these descriptions as more or less true. The future generations will not be so accommodating though: theywill test these answers for their truth. I say this with confidence because I find that more and more people in India are gravitating towards this kind of research. These are not of mere academic interest to such people, whose numbers steadily increase. Many of them realize that Western explanations of their religions and culture trivialize their lived experiences; by distorting, such explanations transform these, and this denies Indians access to their own experiences. It can thus be said to rob them of their inner lives. But that is not all. More than most, they realize that answers to these and allied questions about the nature of Indian culture have the potential to ignite an intellectual revolution on a world scale.«S. N. Balagangadhara: foreword, in Krishnan Ramaswamy / Antonio de Nicolas / Aditi Banerjee (eds.): Invading the Sacred (see note 85), p. vii.

${ }^{88}$ He wrote, »[T] he prevailing knowledge of India among the English-educated elite was generated primarily when India was colonized. Subsequent to the Indian independence, India suffered from poverty and backwardness. In tomorrow's world, the Indian intellectuals will be able to speak back with a newly found confidence and they will challenge European and American descriptions of India. That is, for the first time, they will test the Western knowledge of India and not just accept it as God's own truth."He also argued that, while in the pre-modern period, most communication about specific religious traditions was »from insider to insider, « and during the onset of the modern era, the discussions were among outsiders, this situation changed with Western domination in the colonial period, when »the West began to control the intellectual discourse in its colonies « and the outsider perspectives began to influence the insiders' perspective on their own religions. In the post-colonial world, the flow of communication had now moved »from outsider to insider, to insider to outsider.«Arvind Sharma: Preface, in Krishnan Ramaswamy / Antonio de Nicolas / Aditi Banerjee (eds.): Invading the Sacred. An Analysis of Hinduism Studies in America, New Dehli 2007, xiii.

${ }^{89}$ See also Rambachan Anantanand: Academy and Community: Overcoming Suspicion and Building Trust, in Journal of the American Academy of Religion, 84/2 (2016), pp. $367-372$, who, in the Roundtable on Outrage, Scholarship, and the Law in India argued, »The majority of those who 
research, teach, and speak about the tradition in the western academy are not Hindus. Hindus are appreciative of interest in their tradition, but they are concerned about the consequences of non-Hindu academic scholarship for the tradition. Scholarly work in the academy, despite what some may claim, is never merely descriptive; the predominant kinds of research that are done and the methodologies employed also define a tradition. Therefore, although I understand and appreciate the well-known distinction between teaching religion and teaching about religion, I am not sure that the line of separation is as sharp as some in the academy might represent it to be.« Ibid., p. 369 .

${ }^{90}$ Doniger: A Response (see note 24), P. 366. 